\title{
PROSTHETIC HEART VALVES THROMBOSIS WITH INFECTIOUS ENDOCARDITIS - A PRACTICAL REVIEW
}

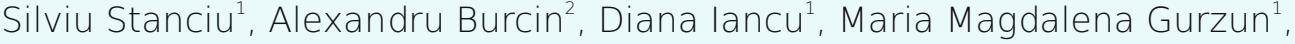 \\ Alexandru Croitoru ${ }^{3}$, Lucian Ciobîcă ${ }^{1}$ \\ "'Dr. Carol Davila" Central Military Emergency University Hospital, Bucharest \\ ${ }^{2}$ Emergency Institute of Cardiovascular Diseases "Prof. Dr. C.C. Iliescu", Bucharest \\ ${ }^{3}$ Faculty of Dental Medicine, UMF "Carol Davila", Bucharest \\ Corresponding author: \\ Silviu Stanciu, silviu.stanciu@yahoo.com
}

\section{Rezumat}

Introducere. Asocierea secvențială sau simultană a trombozei și endocarditei infecțioase la nivelul unei valve mecanice poate reprezenta un scenariu clinic întâlnit rar în practica medicală. Managementul acestor pacienți implică o abordare interdisciplinară, prin integrarea datelor clinice și imagistice, în special a ecografiei transesofagiene tridimensionale. Tomografia computerizată prin emisie de pozitroni poate aduce un aport real în judecarea acestor cazuri atunci când există este disponibilă.

Prezentarea cazului. Prezentăm cazul unui pacient de 65 de ani, cu multiple intervenții chirurgicale pentru boală mitrală reumatismală: valvuloplastie percutanată cu balon în 2008, implantare de proteză mecanică mitrală Liva Nova 33 și anulopastie tricuspidiană - octombrie 2019.

La momentul internării, având în vedere contextul clinic - INR subterapeutic de 2 luni, simptomatologia pacientului și elementele ecografice, s-a stabilit diagnosticul de tromboză de valvă mecanică și s-a inițiat heparinoterapie IV. La o săptămână după transferul pe secția de chirurgie cardiovasculară, statusul clinic al pacientului se deteriorează, cu evoluție către șoc septic. La reevaluarea TEE se remarcă ameliorarea parțială a trombozei de proteză, însă cu apariția elementelor sugestive pentru endocardită infecțioasă.

Discuții și concluzii. Contextul clinic și evaluările ecografice în dinamică constituie cheia diagnosticului la acești pacienți. În cazul nostru au facilitat și crescut probabilitatea unei asocieri secvențiale a celor două complicații, respectiv tromboză urmată de endocardită infecțioasă pe valvă mecanică. Pentru abordarea terapeutică este nevoie de o suspiciune clinică ridicată și de o adaptare promptă a strategiei terapeutice la realitatea patogenică a momentului, intervenția chirurgicală rapidă constituind singura abordare care schimbă prognosticul rezervat al acestor pacienți.

Cuvinte cheie: tromboza de valvă mecanică, endocardita infecțioasă pe proteză, ecocardiografia transesofagiană 3D. FDG-PET/CT. 


\section{INTE}

\section{Abstract}

Simultaneous or sequential combination of prosthetic valve (PV) thrombosis and infectious endocarditis is a rare clinical finding. The management of these patients involves a complex multidisciplinary strategy using clinical judgment and imaging techniques. Transesophageal echocardiography (TEE) and especially 3D transesophageal echocardiography is essential. Moreover, positron emission tomography with fluorodeoxyglucose (F18-FDG PET/CT) can be a valuable tool to diagnose and manage these complicated clinical scenarios.

We present the case of a 65-year-old patient who was admitted in our clinic for paroxysmal nocturnal dyspnea and chills for one week. He had multiple surgical interventions for rheumatic mitral valve disease (percutaneous mitral valvuloplasty in 2008, and mitral valve replacement and tricuspid annuloplasty in October 2019).

At admission, the diagnosis of prosthetic valve thrombosis was established taking into account the clinical context (low INR values for the last two months), the patient symptoms and the echocardiographic findings. IV unfractionated heparin was administered. One week after admission the patient's clinical status further deteriorated. TEE reevaluation showed partial thrombus regression with elements suggestive for concomitant infectious endocarditis.

The diagnosis key is the clinical evolution and repeated TEE evaluations. In our case, they enabled the probable diagnosis of a sequential association of thrombosis and infectious endocarditis on mechanical PV. The therapeutic approach requires a high clinical suspicion and a prompt management, emergent surgery being the only lifesaving strategy in unstable patients with obstructive mechanical pathology.

Keywords: prosthetic valve thrombosis, prosthetic valve endocarditis, 3D transesophageal echocardiography. 


\section{Background}

The simultaneous or sequential combination of thrombosis and infectious endocarditis on prosthetic heart valves is a rare clinical finding. Together or apart, these two entities are often difficult to be diagnosed. The diagnosis and therapeutic strategy should be multifactorial using clinical judgement and imaging techniques, especially 3D transesophageal echocardiography. PET-CT, when available, is a valuable tool for diagnosing and managing this complicated clinical scenarios.

\section{Diagnosis of mechanical prosthetic valve thrombosis}

Transthoracic echocardiography (TTE) is the first-line imaging technique for suspected prosthetic valve complication. It is widely available in most centers and has a high reproducibility in detecting mechanical valve thrombosis. Before performing the exam, it is essential to assess the indication, the type and size of valve prosthesis, the time interval from the surgery and the anticoagulation status. The post-surgery echocardiographic study is necessary for the comparative assessment of the prosthesis parameters ${ }^{(1)}$.

Tranesophageal cardiac echocardiography (TEE) brings information related to the thrombus size, mobility, and location. It is useful in guiding further management when concomitant association of an abscess, fistula, pseudoaneurysm or paravalvular leak. In addition, TEE offers the advantage of better visualizing left atrial appendage, often difficult to assess by $T \mathrm{TE}^{(1)}$.

Cinefluoroscopy (CF) is a cheap, noninvasive technique, available in most centers, that can detect prosthesis obstruction. In the case of bileaflet mechanical valves, the two hemidiscs can be viewed directly and the opening and closing angles can be measured using tangential sections. Although the role of CF has decreased with the widespread use of TEE, it remains a complementary method for assessing mechanical valve obstruction ${ }^{(1)}$.

\section{Multidector computer tomography} (MDCT) is a complementary investigation to TTE, TEE and CF. It is useful especially in patients with two bileaflet mechanical prosthesis (mitral and aortic), but image artifacts and acoustic shadowing can make the interpretation difficult ${ }^{(1)}$.

\section{Diagnosis of infectious endocarditis on mechanical valves}

In patients with infectious endocarditis (IE) on mechanical valves, the clinical presentation is often atypical. Fever, appetite, or weight loss are common onset symptoms. In appropriate clinical context, the appearance of a new valvular regurgitation, a new conduction abnormality on ECG, left ventricular failure or embolic events may represent suggestive elements for infectious endocarditis on mechanical valve ${ }^{(2)}$.

The positive diagnosis for IE is based on the identification of positive blood cultures and ultrasound features (presence of vegetation, paravalvular abscess or fistula, pseudoaneurysm). Blood cultures are rarely positive, especially among patients with early IE on mechanical valve, due to the prophylactic use of antibiotics in the perioperative period ${ }^{(2)}$.

Transesophageal cardiac echography is necessary when mechanical valve endocarditis is suspected of vegetation assessment and evaluation of hemodynamic parameters and potential complications (abscess, fistula, pseudoaneurysm and paravalvular leaks). Its sensitivity ranges between $82-96 \%$ - clearly higher compared to transthoracic cardiac ultrasound (17-36\%). However, the accuracy 
of TTE and TEE in detecting infectious endocarditis on mechanical valves is lower than on native valves ${ }^{(2)}$.

MDCT can acquire detailed anatomical images with high spatial resolution. Performing 3D reconstructions is useful in accurate evaluation of vegetations, abscesses, fistulas or pseudoaneurysms. The disadvantages are related to nephrotoxicity, ionizing radiation exposure and loss of temporal resolution. Unfortunately, there are no current large-scale comparative studies demonstrating a superior specificity of MDCT compared to TEE/TTE for the detection of vegetations and local complications on prosthetic valves ${ }^{(2)}$.

\section{8-F Fluorodeoxyglucose positron} emission tomography/ computer tomography (F18-FDG PET/CT) is an hybrid imaging technique useful for ruling-out infectious endocarditis on prosthetic heart valves when TEE is inconclusive. According to a recent meta-analysis, the sensitivity and specificity of F-FDG PET/CT for diagnosing IE on prosthetic valves vary between $73 \%-96 \%$ and $80-94 \%$, respectively. Highlighting abnormal F18-FDG at the site of an artificial valve has become a major criterion included in the modified Duke criteria, with an increase in sensitivity from $70 \%$ to $97 \%$ without impact on specificity ${ }^{(3)}$. Reactive inflammatory activity in the early stage after prosthesis implantation may lead to false positive diagnosis, while the presence of minor vegetation or previous antibiotic therapy may cause false negative results ${ }^{(4)}$.

F18-FDG/ Magnetic Resonance Imaging FDG/MRI is a relatively new technique, superior to F18-FDG PET/CT due to increased spatial resolution. However, there are no current studies that validate the widespread use of this technique, the accessibility being low due to high costs and longer times of image acquisition ${ }^{(2)}$.

\section{Differential diagnosis}

It is important to establish the diagnosis to choose the optimal management. The different diagnosis of prosthetic valve masses is based on clinical setting, laboratory results, ECG, and multi-modality imaging (Table 1).

\section{Case presentation}

We present the case of a 65-year-old patient who had multiple surgical interventions for rheumatic mitral valve disease: percutaneous mitral valvuloplasty in 2008 , mitral valve replacement with Liva Nova 33 prosthesis and tricuspid annuloplasty in October 2019. He had a history of ischemic stroke with left-sided hemiparesis in 2017, permanent atrial fibrillation, grade II essential hypertension and hyperlipidemia. He was in class III NYHA 
congestive heart failure with mild left ventricular (LV) global systolic dysfunction (LV ejection fraction of $45 \%$ ). He was admitted in our clinic for paroxysmal nocturnal dyspnea and chills lasting for one week.

Physical exam at admission showed blood pressure of $150 / 60 \mathrm{mmHg}$, heart rate (HR) of $66 / \min$, SO2 98\% without supplemental oxygen, no fever, no signs of pulmonary or peripheral congestion, irregularly irregular pulse with a II/NI systolic murmur at apex, audible opening and closing clicks of mitral prosthesis, without any other pathological findings. Laboratory results at admission showed subtherapeutic INR, modest inflammatory syndrome, negative blood and urine cultures and mild normochromic normocytic anemia, most likely hemolytic. Chext X-ray at admission revealed mild cardiomegaly, mitral valve prosthesis, dilated pulmonary hili and right basal pachypleuritis.

The ECG at admission showed atrial fibrillation, HR 90/min, left anterior hemiblock and no repolarization abnormalities. Transesophageal echocardiography was performed at admission. The examination revealed a dysfunctional mitral prosthesis by the presence of an inhomogenous and immobile mass $(12 / 11 \mathrm{~mm})$, which obstructed the hemidisc adjacent to the aortic valve. The mean gradient across the valve was increased (11 $\mathrm{mmHg}$ ) and left atrial appendage thrombosis $(2.5 / 1.1 \mathrm{~cm})$ was visualized. No paravalvular leaks or other elements suggestive for infectious endocarditis were present at that moment. (Figure $1-A, B, C, D$ ) At the time of admission, given the patient symptoms (nocturnal paroxysmal dyspnea that started one week before hospitalization), the clinical context (subtherapeutic INR for the last two months) and the echocardiographic findings, the diagnosis of prosthetic valve thrombosis was established. Infectious endocarditis was also considered among the differential diagnosis, but there were insufficient arguments to support this hypothesis (Table 2). Intravenous heparin at therapeutic doses was initiated. After 7 days of adequate anticoagulation the patient was transferred to the cardiac surgery ward, with persistence of dyspnea, no signs of pulmonary and peripheral congestion, nor fever. After one week, the patient complained of worsening dyspnea, he developed high fever (39 degrees C) and marked increase of inflammatory markers. The thoracic radiography showed an area of consolidation in the right lung and blood cultures were positive with Acinetobacter ursingii, which was highly suggestive for bacterial pneumonia.

Transesophageal cardiac ultrasound was performed given the onset of fever and positive blood cultures. The examination revealed partial thrombus regression at the level of anterior hemidisc, with partial recanalization and normal function of the contralateral hemidisc. There was also persistent left atrial appendage thrombosis. In addition, there was a mobile, inhomogenous, predominantly hypoechoic mass of about 12 $\mathrm{mm}$ near the mitral valve anulus in the paraortic area and a paravalvular leak, which suggested the association of an infectious endocarditis (Figure 2 - A,B,C,D).

\section{Discussion}

Identifying patients who develop concomitant thrombosis and infectious endocarditis on prosthetic valves is a real diagnostic challenge for the cardiologist. The management of such patients requires an interdisciplinary approach between cardiologists, infectious disease specialists and cardiovascular surgeons.

In patients with mechanical valves, it is essential to maintain a strict INR monitoring 
within the therapeutic range specific for the type of valve, to prevent thrombotic complications. The therapeutic target of INR must be adapted according to the patient's risk factors and the thrombogenicity of the prosthesis ${ }^{(5)}$. Increased INR variability has been shown to be an independent predictor of mortality after mechanical valve replacement. Self-monitoring of anticoagulant status reduces INR lability and the risk of thromboembolic events among these patients ${ }^{(6)}$. In clinical practice, prosthetic valve thrombosis is underdiagnosed compared to infectious endocarditis. Mechanical valve thrombosis should be promptly suspected in a patient presenting with sudden onset of dyspnea or embolic events. The diagnosis must be confirmed by transthoracic echocardiography, transeso-phageal echocardiography, cinefluoroscopy or $\mathrm{MDCT}^{(7)}$. Regardless the therapeutic strategy (emergent surgery, fibrinolytic therapy, or anticoagulant therapy), management of valve thrombosis has an increased risk of adverse events ${ }^{(8)}$. Given our patient clinical context, the subtherapeutic anticoagulation status and the absence of hemodynamic instability, we decided to initiate IV heparin therapy followed by repeated transesophageal echography studies.

Prosthetic valve thrombosis may be a risk factor for concomitant infectious endocarditis. The modified Duke criteria have a lower sensitivity compared to native valve endocarditis, making prosthetic endocarditis a diagnostic challenge ${ }^{(9)}$. In both native and prosthetic valves, the positive diagnosis is mainly based on transesophageal echography and blood cultures. Unfortunately, these investigations are frequently negative ${ }^{(10)}$. In addition, the association of mechanical valve thrombosis may further reduce the diagnostic value of transesophageal echocardiography. In the absence of highly suggestive elements of infectious endocarditis, nuclear medicine protocols such as F18-FDG PET/CT can be used to increase diagnostic accuracy ${ }^{(11)}$.

The management of infectious endocarditis requires a multidisciplinary "Endocarditis Team" including cardiologists, cardiovascular surgeons, infectious disease specialists, microbiologists, and neurologists. Thus, by following guideline recommendations and close follow up, the 1-year mortality was significantly reduced from 18.5 to $8.2 \%$ in countries like France ${ }^{(12,13)}$.

\section{Conclusions}

The diagnosis key is the patient's clinic and repeated transesophageal ultrasound evaluations. In our case, they enabled the probable diagnosis of a sequential association of thrombosis and infectious endocarditis on mechanical valve. The therapeutic approach requires a high clinical suspicion and a prompt management, emergent surgery being the only lifesaving strategy in hemodynamically unstable patients with obstructive mechanical pathology. 


\begin{tabular}{|c|c|c|c|}
\hline & Thrombus & Pannus & Vegetation \\
\hline Morphology & $\begin{array}{l}\text { Hipodensity, } \\
\text { irregular borders, } \\
\text { homogenous } \\
\text { myocardial } \\
\text { echogenicity. }\end{array}$ & $\begin{array}{l}\text { Semicircular/circular } \\
\text { echodensity with calcium } \\
\text { deposits. }\end{array}$ & $\begin{array}{l}\text { Pedunculated mass, initial } \\
\text { echogenicity is simillar to } \\
\text { a thrombus; it increases } \\
\text { proportionally with the } \\
\text { age of the vegetation. }\end{array}$ \\
\hline Localization & $\begin{array}{l}\text { Occluder, hinges +/- } \\
\text { valve struts. }\end{array}$ & $\begin{array}{l}\text { Mitral: atrial/ventricular } \\
\text { sides. } \\
\text { Aortic: aortic and/or left } \\
\text { ventricular outflow tract } \\
\text { side. }\end{array}$ & $\begin{array}{l}\text { Attached on the low- } \\
\text { pressure side of the } \\
\text { prosthesis. }\end{array}$ \\
\hline Mobility & Fixed/Immobile & Immobile & $\begin{array}{l}\text { High mobility, oscillating } \\
\text { or nonoscillating mass } \\
\text { (mobility increases with } \\
\text { increasing vegetation } \\
\text { size) }\end{array}$ \\
\hline 3D ECHO & $\begin{array}{l}\text { Irregular mass that } \\
\text { obstructs the inflow } \\
\text { and outflow orifices, } \\
\text { with extension on } \\
\text { both sides of the } \\
\text { prosthesis, } \\
\text { frequently near the } \\
\text { hinge region. }\end{array}$ & $\begin{array}{l}\text { Purple or violet-colored } \\
\text { echo density on a bright } \\
\text { cream color base of the } \\
\text { endothelialized sewing } \\
\text { ring surrounding the } \\
\text { prosthetic valve suture } \\
\text { line. }\end{array}$ & $\begin{array}{l}\text { Accurately provides the } \\
\text { entire morphology and } \\
\text { maximum size of the } \\
\text { vegetation, leading to a } \\
\text { better prediction of risk of } \\
\text { embolism compared to } 2 \mathrm{D} \\
\text { echo. } \\
\text { Paravalvular leak }\end{array}$ \\
\hline MDCT & $\begin{array}{l}\text { Hipodensity (<90 } \\
\text { UH) }\end{array}$ & Hiperdensity (>145 UH) & $\begin{array}{l}\text { High-resolution } \\
\text { anatomical and metabolic } \\
\text { imaging of the prosthesis } \\
\text { and its surrounding } \\
\text { anatomy, combined with } \\
\text { FDG-PET }\end{array}$ \\
\hline Complications & $\begin{array}{l}\text { LAA thrombosis, } \\
\text { pulmonary/systemic } \\
\text { embolic events, } \\
\text { acute pulmonary } \\
\text { edema, cardiogenic } \\
\text { shock. }\end{array}$ & $\begin{array}{l}\text { Prosthetic valve } \\
\text { obstruction, congestive } \\
\text { heart failure, cardiogenic } \\
\text { shock. }\end{array}$ & $\begin{array}{l}\text { Abcess, pseudoaneurysm, } \\
\text { perforation, paravalvular } \\
\text { leak, valve dehiscence, } \\
\text { septic shock. }\end{array}$ \\
\hline
\end{tabular}

Table 1. Prosthetic valve masses - differential diagnosis. Adapted from Mustafa Ozan Gürsoy, MaciKalçık, Mahmut Yesin, Süleyman Karakoyun, Emrah Bayam, Sabahattin Gündüz, and Mehmet Özkan. A global perspective on mechanical prosthetic heart valve thrombosis: Diagnostic and therapeutic challenges ${ }^{(1)}$ 
Clinical Cases.

\begin{tabular}{|c|c|}
\hline Arguments for prosthetic valve thrombosis & $\begin{array}{l}\text { Arguments for prosthetic valve } \\
\text { endocarditis }\end{array}$ \\
\hline \multicolumn{2}{|l|}{ History and clinical status } \\
\hline $\begin{array}{l}\text { Dyspnea on minimal exertion, paroxysmal nocturnal } \\
\text { dyspnea } 2 \text { weeks before admission. }\end{array}$ & $\begin{array}{l}\text { Recent infective endocarditis, } \\
\text { antibiotic treatment with clinical, } \\
\text { biological, and echocardiographic } \\
\text { remission. }\end{array}$ \\
\hline No fever & Chills \\
\hline $\begin{array}{l}\text { Suboptimal INR }(<1.4) \text { for } 2 \text { months after mitral valve } \\
\text { prosthesis implantation }\end{array}$ & \multirow{4}{*}{$\begin{array}{l}\text { Modest increase of inflammatory } \\
\text { markers at admission (CRP:11.34 } \\
\text { mg/L; VSH: } 66 \text { mm/H) }\end{array}$} \\
\hline Negative blood cultures at admission & \\
\hline Normal WBC & \\
\hline Procalcitonin $<0.5 \mathrm{ng} / \mathrm{ml}$ & \\
\hline \multicolumn{2}{|l|}{ Echocardiography } \\
\hline $\begin{array}{l}\text { Prosthetic valve obstruction; Medium transprosthetic } \\
\text { gradient - } 11 \mathrm{mmHg} \text {; PHT - } 170 \mathrm{~ms} .\end{array}$ & - \\
\hline $\begin{array}{l}\text { Fixed, isoechogenic mass }(\sim 1 \mathrm{~cm}) \text { which obstructs the } \\
\text { hemidisc near the aortic valve; similar echogenicity to } \\
\text { the LAA (left atrial appendage) thrombus. } \\
\text { LAA thrombosis }(2.5 / 1 \mathrm{~cm}) \\
\text { No paravalvular leak. } \\
\text { No mobile masses }\end{array}$ & - \\
\hline \multicolumn{2}{|l|}{ Treatment } \\
\hline $\begin{array}{l}\text { Remission of symptoms after } 7 \text { days of IV heparin } \\
\text { treatment }\end{array}$ & - \\
\hline
\end{tabular}

Table 2. Clinical arguments for prosthetic valve thrombosis/endocarditis at admission 

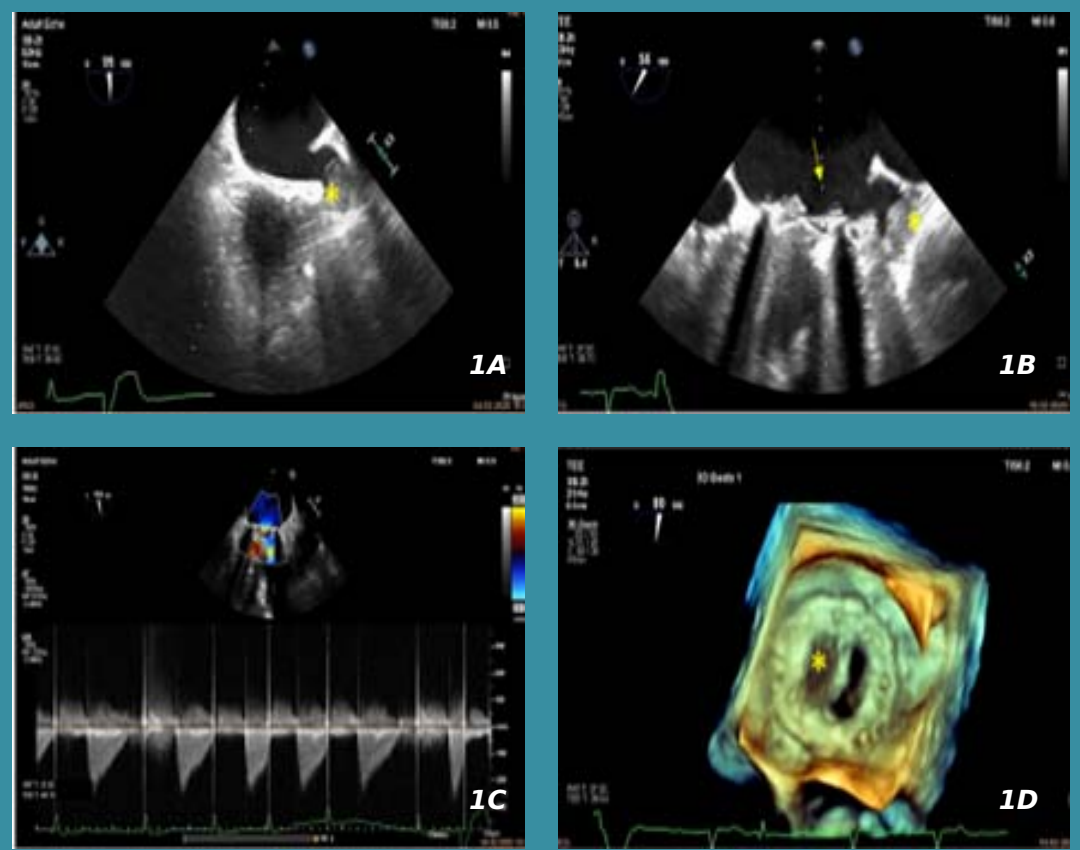

Figure 1. Transesophageal echocardiography at admission 1.A. Transesophageal echocardiography (TEE), midesophageal modified 2-chamber view for left atrial appendage (LAA) shows an organized thrombus. (asterisk) 1B. TEE, mid-esophageal view: bileafleat mechanical prosthetic valve (PV) and an organized thrombus in the LAA (asterisk). And imobile mass $(\sim 1 \mathrm{~cm})$ with a similar echogenicity to the LAA thrombus is causing partial obstruction of the PV due to stuck leaflet. 1C. TEE, mid-esophageal 3chamber view. MV prosthesis Continuous-wave Doppler shows an increased transvalvular gradient and a long PHT (11 mmHg and $170 \mathrm{~ms}$ respectively) 1D. 3D TEE - Prosthetic mitral valve visualized from a left atrial view with a large mass attached to a hemidisc (asterisk), suggestive for PV thrombosis.
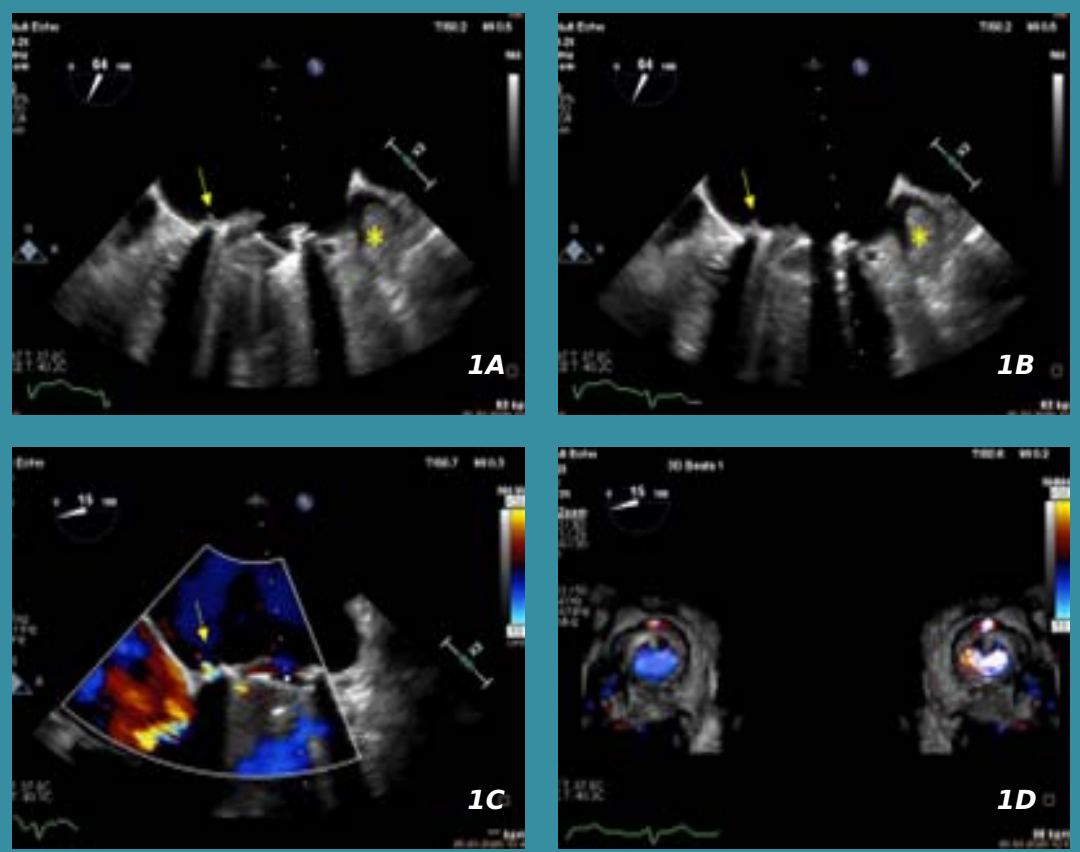

Figure 2. Transesophageal echocardiography reevaluation 2A-B. 2D - TEE reevaluation after 30 days. Mid-esophageal view - A mobile mass attached to the same hemidisc which determines obstruction during both systole (left) and diastole (right), with a modest improvement after seven days of heparin treatment. Small mobile elements attached to the hemidisc (arrow) suggestive for prosthetic valve endocarditis associated with valve thrombosis. The well organized thrombus in the LAA can also be seen. (asterisk) 2C. TEE - Mid-esophageal view. A new regurgitant paraprosthetic jet is seen at color Doppler. 2D. 3D visualization of the paravalvular leak from LV and LA perspective. 


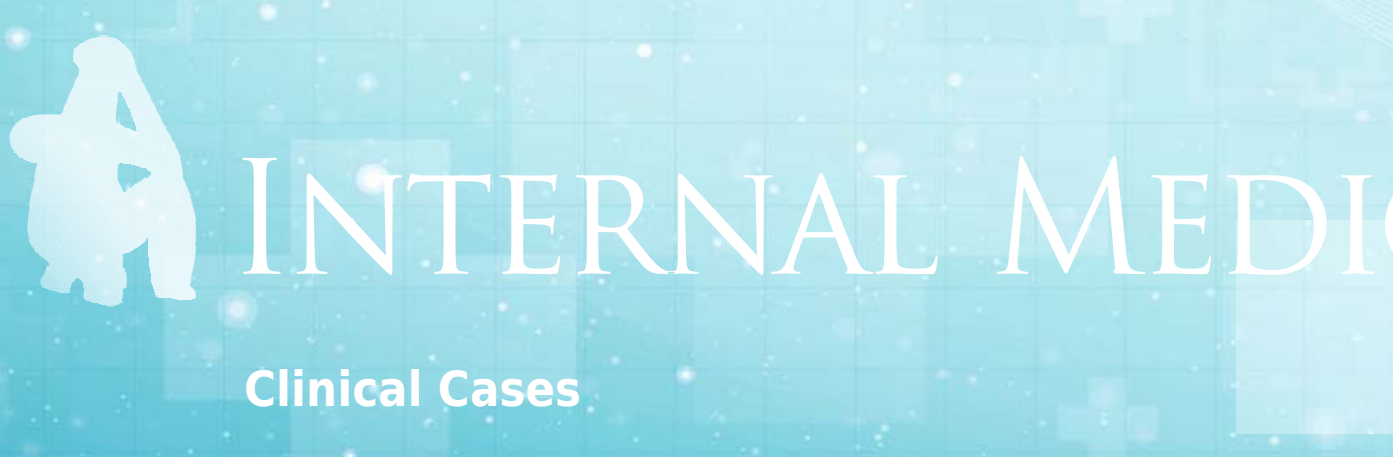

\section{References}

1. Gürsoy, M., Kalçık, M., Yesin, M., Karakoyun, S., Bayam, E., Gündüz, S., \& Özkan, M. (2016, December). A global perspective on mechanical prosthetic heart valve thrombosis: Diagnostic and therapeutic challenges.

2. IvanoviC B;Trifunovic D;Matic S;Petrovic J;Sacic D;Tadic M;. (n.d.). Prosthetic valve endocarditis - A trouble or a challenge?

3. Saby L, Laas O, Habib G. Positron emission tomography/computed tomography for diagnosis of prosthetic valve endocarditis: increased valvular 18Ffluorodeoxyglucose uptake as a novel major criterion. J Am Coll Cardiol 2013;61:2374-82.

4. Mahmood M, Kendi AT,Ajmal S, Farid S, O'Horo JC, Chareonthaitawee $P$, et al. Metaanalysis of 18F-FDG PET/CT in the diagnosis of infective endocarditis. J NuCl Cardiol 2017

5. Butchart EG, Gohlke-Barwolf C, Antunes MJ, Tornos P, De Caterina $R$, Cormier $B$, Prendergast $B$, lung $B$, Bjornstad $H$, Leport C, Hall RJ, Vahanian A, Working Groups on Valvular Heart Disease, Thrombosis, and Cardiac Rehabilitation and Exercise Physiology, European Society of Cardiology. Recommendations for the management of patients after heart valve surgery. Eur Heart J 2005;26:2463-2471.

6. Heneghan C, Ward A, Perera R, Bankhead C, Fuller A, Stevens R, Bradford K, Tyndel S, Alonso-Coello P, Ansell J, Beyth R, Bernardo A, Christensen TD, Cromheecke ME, Edson RG, Fitzmaurice D, Gadisseur AP, Garcia-Alamino JM, Gardiner C, Hasenkam JM, Jacobson A, Kaatz S, Kamali F, Khan TI, Knight E, Kortke H, Levi M, Matchar D, MenendezJandula B, Rakovac I, Schaefer C, Siebenhofer A, Souto JC, Sunderji R, Gin K, Shalansky K, Voller H, Wagner $O$, Zittermann A. Self-monitoring of oral anticoagulation: systematic review and meta-analysis of individual patient data. Lancet 2012;379:322-334.

7. Lancellotti P, Pibarot $P$, Chambers J, Edvardsen $T$, Delgado V, Dulgheru R, Pepi M, Cosyns B, Dweck MR, Garbi M, Magne J, Nieman K, Rosenhek R, Bernard A, Lowenstein
J, Vieira ML, Rabischoffsky A, Vyhmeister $R H$, Zhou $X$, Zhang Y, Zamorano JL, Habib G. Recommendations for the imaging assessment of prosthetic heart valves: a report from the European Association of Cardiovascular Imaging endorsed by the Chinese Society of Echocardiography, the InterAmerican Society of Echocardiography, and the Brazilian Department of Cardiovascular Imaging. Eur Heart J Cardiovasc Imaging 2016;17:589-590.

8. Baumgartner, H., Falk, V., Bax, J., De Bonis, M., Hamm, C., Holm, P., . . . Zamorano, J. (2017, August 26). 2017 ESC/EACTS Guidelines for the management of valvular heart disease.

9. Lamas CC, Eykyn SJ. Suggested modifications to the Duke criteria for the clinical diagnosis of native valve and prosthetic valve endocarditis: analysis of 118 pathologically proven cases. Clin Infect Dis 1997;25:713-719.

10. Habib G, Derumeaux G, Avierinos JF, Casalta JP, Jamal $F$, Volot $F$, Garcia M, Lefevre J, Biou F, MaximovitchRodaminoff A, Fournier PE, Ambrosi P, Velut JG, Cribier A, Harle JR, Weiller PJ, Raoult D, Luccioni R. Value and limitations of the Duke criteria for the diagnosis of infective endocarditis. J Am Coll Cardiol 1999;33: 2023-2029.

11. Rouzet F, Chequer R, Benali K, Lepage L, Ghodbane W, Duval $X$, lung $B$, Vahanian $A$, Le Guludec $D$, Hyafil $F$. Respective performance of 18F-FDG PET and radiolabeled leukocyte scintigraphy for the diagnosis of prosthetic valve endocarditis. J Nucl Med 2014;55:1980-1985.

12. Habib, G., Lancellotti, P., Antunes et al (2015, November 21). 2015 ESC Guidelines for the management of infective endocarditis: The Task Force for the Management of Infective Endocarditis of the European Society of Cardiology (ESC) Endorsed by: European Association for Cardio-Thoracic Surgery (EACTS), the European Association of Nuclear Medicine (EANM).

13. Botelho-Nevers $E$, Thuny $F$, Casalta JP, Richet $H$, Gouriet F, Collart F, Riberi A, Habib G, Raoult D. Dramatic reduction in infective endocarditis-related mortality with a management-based approach. Arch Intern Med 2009;169:1290-1298 